\title{
THE EFFECT OF SELECTED PLANT MATERIALS AND EXTRACTS ON THE DEVELOPMENT OF BACTERIAL DISEASES ON ONION
}

\author{
Beata KOWALSKA, Urszula SMOLIŃSKA \\ Research Institute of Vegetable Crops \\ Konstytucji 3 Maja 1/3, 96-100 Skierniewice, Poland
}

Received: April 8, 2008; Accepted: June 10, 2008

\begin{abstract}
Summary
The effects of Brassicaceae and Solanaceae plant residues and water extracts from these residues on the growth of onion (Allium cepa L.) pathogenic bacteria Pectobacterium carotovorum subsp. carotovorum, Burkholderia cepacia and Burkholderia gladioli pv. alliicola were examined. The influence of these materials on the development of bacterial diseases on onion bulbs was also investigated. The toxic effect depended on the kind and amount of the agent used and also on the species of examined bacteria. The water extract from Brassica napus cv. Kana and water extract from Lycopersicon esculentum cv. Remiz decreased a density of three examined bacteria in nutrient broth medium. Also milled seeds of Brassica juncea cv. Małopolska expressed an inhibitory effect towards B. cepacia and B. gladioli pv. alliicola. However, milled seeds of $B$. napus cv. Kana used as an addition to liquid medium did not decrease the density of these bacteria. In the experiment on onion bulbs the most promising results were obtained for milled seeds of $B$. juncea cv. Małopolska. This material used both as a source of volatile compounds and also in direct contact with the inoculated place on the onion bulb, inhibited diseases development caused by all three examined bacteria. B. juncea contains very high concentration of 2propenyl ITC and probably this compound caused decrease in density of bacteria and the reduction of disease development. Purified, commercially obtained 2-propenyl ITC proved a very strong antibacterial activity and also inhibited disease development on onion. The commercial products Funguran Easy 50 WP and Biosept 33SL were also used but they showed very weak activity in protection of onion against the tested bacteria.
\end{abstract}

key words: bacterial disease, onion, biological control

\section{INTRODUCTION}

Bacterial pathogens and their control are a serious problem in agriculture practice (Sobiczewski \& Schollenberger 2002). Antibiotics are forbidden in

Corresponding author:

e-mail: beatakow@inwarz.skierniewice.pl

(C) Copyright by RIVC 
many countries, especially in protection of vegetables. Copper compounds, because of their general toxicity, exert a negative impact on both yield and the environment and their use is on the way to be restricted and controlled in the European Union (Iacobellis \& Cantore 2005).

Low assortment and the requirement of reduction in the use of pesticides in agriculture, prompts the need for the development of alternative methods for the control of plant bacterial diseases. Especially, agents which can be used in integrated crop management as well as in bio-organic agriculture are searched. Natural biologically active compounds produced in plants are being tested for their antimicrobial activity. Plants are rich in secondary metabolites with potential use in phytomedicine e.g. alkaloids, flavonoids, glucosinolates (Cowan 1999). Hence, it is a big chance to use these plants in biocontrol of bacterial diseases of vegetables. In recent years a large number of compounds from different plants has been investigated for their antimicrobial properties against plant pathogenic bacteria and also fungi (Martyniuk et al. 1999, Krupiński \& Sobiczewski 2001, Smolińska 2004, Kokoškovă \& Roman 2005, Łojkowska et al. 2005, Tabanca et al. 2007, Bahraminejad et al. 2008). For instance Daferera et al. (2003) and also Soylu et al. (2005) investigated effect of plant essential oils on the growth Clavibacter michiganensis subsp. michiganensis. Colony forming ability of the microorganism was completely inhibited by oregano, thyme and dictamnus oils. Vasinauskiene et al. (2006) showed toxic activity of essential oils towards Xanthomonas vesicatoria, Pseudomonas syringae, Pseudomonas marginalis pv. marginalis and Bacillus sp. Aerial parts of medicinal plant Ziziphora clinopodioides have a strong and broad spectrum of antibacterial activity against many bacteria, also Pectobacterium carotovorum subsp. carotovorum and Erwinia chrysanthemi (Ozturk \& Ercisli 2007). Also extract from Allium sativum has the potential to inhibit the common genera of plant pathogenic bacteria e.g. Pectobacterium carotovorum, Pseudomonas syringae, Xanthomonas campestris (Curtis et al. 2004). Coventry \& Allan (2001) investigated antibacterial activity of neem-based products towards several bacteria e.g. Xanthomonas campestris, Pectobacterium carotovorum subsp. carotovorum, Pseudomonas syringae pv. phaseolicola, Agrobacterium tumefaciens. The agar diffusion assay clearly showed that neem extracts have antibacterial activity towards some tested bacteria.

There is a lot of literature about insecticidal, nematicidal, fungicidal and phytotoxic effects of active compounds from Brassica plants. Also, compounds occurred in plants Brassicaceae may strongly influence on bacterial populations (Brown \& Morra 1997, Rosa \& Rodrigues 1999). Members of the Brassicaceae family contain a class of chemicals known as glucosinolates. They are stored in vacuoles of cells of all tissue types within plant (Gardiner et al. 1999). Glucosinolates are considered to have biological activity after an occurence of tissue damage. Then, these molecules are cleaved by $\beta$-tioglucosidase producing many active compounds including, among others, thiocyanates, isothiocyanates, nitriles (Horbowicz 2003). 
Numerous Solanaceae plants contain various glycoalkaloids, which are considered to be natural toxins and act synergistically against pathogens (Lachman et al. 2001).

In the last years bacterial diseases of onion cause very serious problems. These diseases may cause significant economic losses because they are difficult to control. Losses in production and storage of onion crops are caused by some species of bacteria, e.g. Pectobacterium carotovorum subsp. carotovorum (Erwinia carotovora subsp. carotovora), Burkholderia cepacia and Burkholderia gladioli pv. alliicola. Soft rot of onion bulbs caused by these bacteria is common during cultivation, storage or transportation. Especially, it may develop in the field after heavy rains before harvest (Sobiczewski \& Schollenberger 2002). While several biological control agents are commercially available for fungal plant pathogens, relatively few are available for bacterial plant pathogens. Nowadays only one product containing extract from grapefruit is suggested for control bacterial diseases of onion but unfortunately, it is not always efficient (Orlikowski \& Skrzypczak 2003). Hence, a new method for control of these diseases is needed.

Accordingly, the aim of this work was to examine the effects of Brassicaceae and additionally Solaneceae plant residues or water extracts from these material on the growth of Burkholderia cepacia, Burkholderia gladioli pv. alliicola and Pectobacterium carotovorum subsp. carotovorum.

\section{MATERIAL AND METHODS}

Phytopathogenic bacterial strains: B. cepacia, B. gladioli pv. alliicola and $P$. carotovorum subsp. carotovorum were obtained from Belgian Microorganism Collection. The strains were stored in $-80^{\circ} \mathrm{C}$ in nutrient broth medium with glycerol (1:1). These strains were used in all described experiments.

The effect of plant materials on the growth of bacteria was investigated in the laboratory experiments. Following plant materials were used: milled seeds of mustard Brassica juncea cv. Małopolska, milled seeds of rapeseed Brassica napus cv. Kana, water extract from dry upper parts of the rapeseed and water extract from dry upper parts of tomato Lycopersicon esculentum cv. Remiz. Plants of B. napus cv. Kana were sown in field microplots at the end of April and harvested in June. Plants of $L$. esculentum cv. Remiz were cultivated in a glasshouse also from April to June. These both materials were dried in an air flow in a laboratory cabinet dryer at $45^{\circ} \mathrm{C}$ for $24 \mathrm{~h}$. The dry plants were crushed and kept in darkness in tighly clossed glass jars. Then, 48-h water extracts were prepared in ratio 1:5 or 1:3 for rapeseed and tomato, respectively. The extracts were sterilized in autoclave for $20 \mathrm{~min}$ at $121^{\circ} \mathrm{C}$.

$50 \mathrm{ml}$ of nutrient broth (NB) medium (Schaad et al. 2001) was inoculated with the $24 \mathrm{~h}$ old bacteria. Next the plant material was added into the flask. Following plant materials were used: milled seeds of mustard $(5 \% \mathrm{wt} / V)$ and milled seeds of rapeseed $(5 \%$ and $10 \% \mathrm{wt} / V)$ against B. cepacia and B. gladioli pv. alliicola; water extract from dry material of rapeseed at the concentration 10, 20 
and $30 \%(\mathrm{v} / \mathrm{V})$ and water extract from dry material of tomato at the concetration $10 \%(\mathrm{v} / V)$ against all three examined bacteria. Control treatment was NB medium inoculated with bacteria only. There were two replicates (flasks) for each treatment. Incubation lasted 24 or 48 hours in $30^{\circ} \mathrm{C}$. Afterwards by plate count technique the number of colony forming units per $1 \mathrm{~mL}(\mathrm{CFU} / \mathrm{mL})$ was estimated. When sterilized extracts were used, the density of bacteria was determined on nutrient agar medium (NA) (Schaad et al. 2001). In case of not sterilized material (milled seeds of mustard and rapeseed), selective medium PCAT (Salles et al. 2006) for B. cepacia and B. gladioli was used to estimate density of these bacteria. PCAT medium consists of: azelaic acid $2 \mathrm{~g}$, tryptamine $0.2 \mathrm{~g}$, $\mathrm{MgSO}_{4} \times 7 \mathrm{H}_{2} \mathrm{O} 0.1 \mathrm{~g}, \mathrm{KH}_{2} \mathrm{PO}_{4} 4 \mathrm{~g}, \mathrm{~K}_{2} \mathrm{HPO}_{4} 4 \mathrm{~g}$, yeast extract $0.02 \mathrm{~g}$, agar $15 \mathrm{~g}$, water $1000 \mathrm{~mL}$. After autoclaving the medium was supplemented with $1 \mathrm{~mL}$ of chlorothalonil. The experiments were conducted three times.

One of the most active compounds released from mustard tissues is 2propenyl isothiocyanate (2-propenyl ITC). The antibacterial effect of commercial 2-propenyl ITC (Sigma) was evaluated in a laboratory experiment. All tested bacterial strains were grown in NB medium (Schaad et al. 2001) for $24 \mathrm{~h}$ at $30^{\circ} \mathrm{C}$. Then $100 \mu \mathrm{L}$ of prepared serial dilutions of the suspension was plated on Petri dishes ( $5 \mathrm{~cm}$ in diameter) with NA medium. Four Petri dishes without the lids were placed into a large Petri dish $\left(19 \mathrm{~cm}\right.$ in diameter, volume $\left.314 \mathrm{~cm}^{3}\right)$ which was used as an incubation chamber. Additionally, a piece of filter paper $(1 \mathrm{~cm} \times 1 \mathrm{~cm})$ was put into the middle of the large dish and 2-propenyl ITC at the dosage $5,10,20 \mu \mathrm{L}$ was dropped onto it. Immediately the dish was tighly closed and sealed with plastic film. The Petri dish without 2-propenyl ITC served as a control. All dishes were incubated $48 \mathrm{~h}$ at $30^{\circ} \mathrm{C}$. Then the number of colony forming units was estimated. There were two replicates (large Petri dishes) per each treatment. The experiment was conducted three times.

The effectiveness of plant materials, water extracts from these materials and two commercial products on the development of bacterial diseases on onion bulbs was investigated. Bulbs of onion cv. Grabowska were peeled, washed with running water and sterilized in ethanol for $30 \mathrm{sec}$. Then the bulbs were washed in sterile water and cut lengthwisely into two parts. Three onion pieces were placed into a large Petri dish - incubation chamber (volume $314 \mathrm{~cm}^{3}$ ), on paper filter which was earlier wetted with $10 \mathrm{~mL}$ of water. The outer scale of each piece was wounded with a small laboratory needle to make a wound $3-4 \mathrm{~mm}$ in diameter. This place was inoculated with $20 \mu \mathrm{L}$ of $24-\mathrm{h}$ bacterial suspension in NB medium at density $1.0-2.5 \times 10^{8} \mathrm{cfu} \cdot \mathrm{mL}^{-1}$. Then the effect of several methods against development of bacterial diseases on onion bulbs was studied:

1. Effect of volatile compounds:

a) evolved from seeds of mustard B. juncea cv. Małopolska - $8 \mathrm{~g}$ of milled seeds was put into a small Petri plate with $10 \mathrm{~cm}^{3}$ water; next this open plate was put into the incubation chamber,

b) evolved from $20 \mu \mathrm{L}$ of 2-propenyl ITC; the compound was dropped into a small Petri plate which was put into the middle of the incubation chamber. 
2. Direct effect of plant material:

a) about 15-20 mg of milled seeds of mustard B. juncea cv. Małopolska was sprayed onto place on onion bulb inoculated with bacteria,

b) about $15-20 \mathrm{mg}$ of milled seeds of rapeseed B. napus cv. Kana was sprayed onto place on onion bulb inoculated with bacteria.

3. Effect of water extracts

a) $20 \mu \mathrm{L}$ of tomato water extract was dropped onto the inoculation place on onion bulb. The extract was prepared from fresh plant material of tomato cv. Remiz, in ratio 1:3, for $48 \mathrm{~h}$.

4. Effect of commercial products

a) $20 \mu \mathrm{L}$ of Funguran Easy $50 \mathrm{WP}$ at the concentration $3 \mathrm{~g} \cdot \mathrm{L}^{-1}$ was dropped onto the inoculation place on onion bulb,

b) $20 \mu \mathrm{L}$ of Biosept 33SL at the concetration $3 \mathrm{~g} \cdot \mathrm{L}^{-1}$ was dropped onto the inoculation place on onion bulb.

Immediately after addition of the biological agent the dish was tighly closed and sealed with plastic film. The inoculated with bacteria and uninoculated control was also included.

The experiment was replicated three times and each experiment comprised 2-3 replicates (incubation chamber) of each bacterial strain. The experiment was conducted in the laboratory, in the growing chamber (SANYO) with relative humidity of about $60 \%$, at $30^{\circ} \mathrm{C}$ in the dark for 6 days. The following disease index was used: 0 - no disease symptoms, 1 - about $30 \%$ of bulb with disease symptoms, 2 - about $65 \%$ of bulb with disease symptoms, 3 - about $100 \%$ of bulb with disease symptoms.

All data was subjected to analysis of variance and the Newman-Keuls test was used to estimate the significance of difference between the means $(\mathrm{P}=0.05)$.

\section{RESULTS AND DISCUSSION}

The results of the present study showed that examined Brassicaceae and Solanaceae plant residues and water extracts from these materials exhibited inhibitory activity against $P$. carotovorum subsp. carotovorum, B. cepacia and B. gladioli pv. alliicola. The effect depended on the kind and amount of agent used and species of examined bacteria.

The antibacterial activities of the plant materials against onion pathogenic bacteria were assayed in vitro and also in vivo in incubation chamber with onion bulbs. Growth of B. cepacia and B. gladioli pv. alliicola in liquid medium was inhibited in different extent after addition of milled seeds of $B$. juncea cv. Małopolska (5\%), water extract from B. napus cv. Kana (20 and 30\%) and water extract from $L$. esculentum $\mathrm{cv}$. Remiz (10\%). The strongest activity against $B$. cepacia and B. gladioli pv. alliicola showed milled seeds of $B$. juncea. The material caused 70-fold and about 1000-fold decrease in number of B. cepacia and B. gladioli pv. alliicola, respectively (Fig. 1). Unfortunately, $P$. carotovorum subsp. carotovorum was not examined in this experiment because a selective medium for the bacterium was not available. Promising results with $B$. 
juncea were obtained also in experiments with onion bulbs with all three examined bacteria. The greatest reduction in disease development was observed both when the material was used as a powder sprinckled on inoculated onion and also when it was used as a source of volatiles compounds (Table 1).

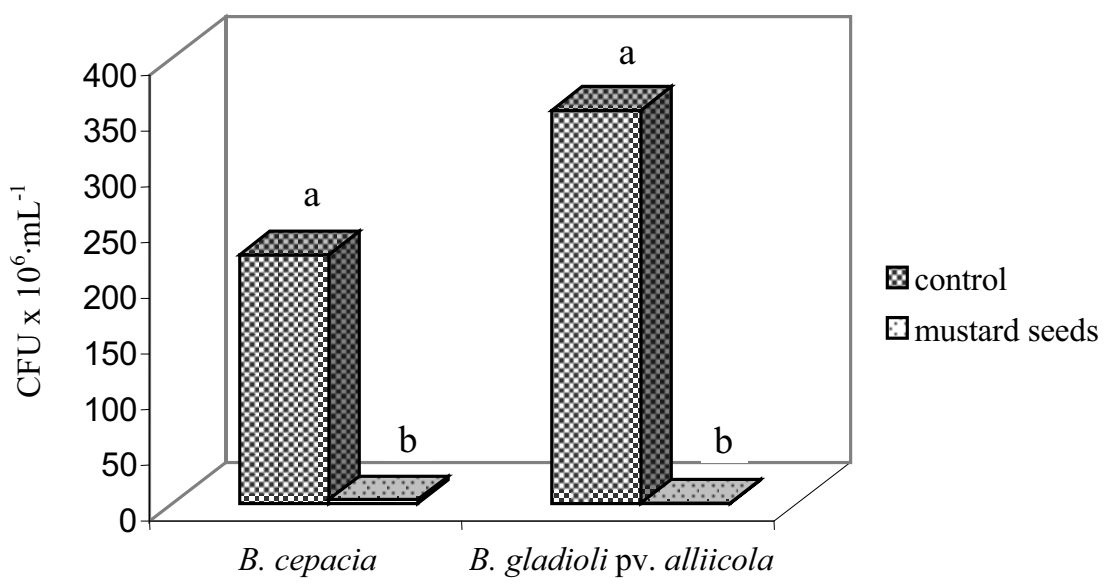

Fig. 1. The effect of milled seeds of mustard B. juncea cv. Małopolska on the growth of B. cepacia and B. gladioli pv. alliicola

Numbers with the same letter are not significantly different according to Newman-Keuls test $(\mathrm{P}=0.05)$.

Table 1. The effect of plant materials and commercial agents on the disease development of onion bulbs caused by B. cepacia, B. gladioli pv. alliicola and P. carotovorum subsp. carotovorum.

\begin{tabular}{lccc}
\hline & \multicolumn{3}{c}{ Disease rate of onion* } \\
\cline { 2 - 4 } \multicolumn{1}{c}{ Treatment } & B. cepacia & $\begin{array}{c}\text { B. gladioli } \\
\text { pv. allicola }\end{array}$ & $\begin{array}{c}\text { P. carotovorum } \\
\text { subsp. } \\
\text { carotovorum }\end{array}$ \\
\hline infected control & $3.0 \mathrm{a}$ & $2.5 \mathrm{a}$ & $2.7 \mathrm{a}$ \\
volatile compounds evolved from & $0.62 \mathrm{~cd}$ & $0.5 \mathrm{c}$ & $1.3 \mathrm{bc}$ \\
seeds of mustard & $1.0 \mathrm{c}$ & $0.08 \mathrm{c}$ & $0.97 \mathrm{bc}$ \\
milled seeds of mustard & $2.2 \mathrm{~b}$ & $0.37 \mathrm{c}$ & $1.2 \mathrm{bc}$ \\
milled seeds of rapeseed & $3.0 \mathrm{a}$ & $1.3 \mathrm{~b}$ & $1.8 \mathrm{ab}$ \\
water extract from tomato & $2.8 \mathrm{ab}$ & $2.6 \mathrm{a}$ & $2.9 \mathrm{a}$ \\
Funguran EASY 50WP & $3.0 \mathrm{a}$ & $2.0 \mathrm{ab}$ & $2.85 \mathrm{a}$ \\
Biosept 33SL & $0.0 \mathrm{~d}$ & $0.0 \mathrm{c}$ & $0.0 \mathrm{c}$ \\
volatile compound (2-propenyl ITC) & & & \\
\hline
\end{tabular}

Means followed by the same letter do not differ significantly.

* The effect of disease development was expressed in the folowing scale: 0-3, where: 0 - no disease symptoms, 1 - about $30 \%$ of bulb with disease symptoms, 2 - about $65 \%$ of bulb with disease symptoms, 3 - about $100 \%$ of bulb with disease symptoms 
Antibacterial activity of $B$. juncea was especially expressed for $B$. gladioli pv. alliicola and B. cepacia. In case of $P$. carotovorum subsp. carotovorum its effect was slightly weaker but also significantly differed compared with inoculated control (Photo 1).

The analysis of the content of glucosinolates in Brassicaceae plants showed that $B$. juncea contains very high concentration of 2-propenyl ITC, e.g. $648 \mu \mathrm{g} \cdot \mathrm{g}^{-1}$ in dry plant tissues (Smolińska \& Horbowicz 1999). Probably this compound caused the reduction of disease development and decrease in density of bacteria in the conducted experiments. To confirm our assumption purified commercially obtained 2-propenyl ITC was used in the next experiment. The results presented in Table 2 indicated that this compound could be responsible for such good antibacterial activity. Even minimal amount of pure 2-propenyl ITC $\left(5 \mu \mathrm{L}\right.$ per volume $\left.314 \mathrm{~cm}^{3}\right)$ used as a volatile compound, proved a very strong antibacterial activity. It reduced number of bacteria growing on nutrient agar on the Petri plate in the presence of the compound (Photo 3). The effect was very similar in case of all examined bacteria. The antibacterial effect of 2propenyl ITC was confirmed in the experiment with onion bulbs - the development of bacterial disease was completely inhibited by this volatile compound (Table 1). Efficacy of volatile compounds released from plant tissues in inhibiting the growth of vegetable pathogenic bacteria was investigated also by Brown \& Morra (1997). They found that some isothiocyanates were strong inhibitors of bacterial growth, e.g. Bacillus subtilis and Pseudomonas aeruginosa. Utama et al. (2002) showed that some aldehydes obtained from plants had toxic activity towards Pectobacterium carotovorum and Pseudomonas aeruginosa.

The antibacterial activity of milled seeds of rapeseed (Brassica napus cv. Kana) was also examined in in vitro and in vivo experiments. The material gave promising results especially in reducing disease development caused by $B$. gladioli pv. alliicola (Photo 2) and P. carotovorum subsp. carotovorum (Table 1). It reduced disease development by $85 \%$ and $56 \%$ respectively. However, this material added to NB medium at $5 \%$ and $10 \%(\mathrm{wt} / V)$ concentration, did not influence the survival of examined bacteria (results not presented).

The effect of water extract from rapeseed cv. Kana on the growth of the pathogenic bacteria was examined. The obtained results were dependent on its concentration in the nutrient broth. The growth of all tested bacteria was reduced when $20 \%$ and $30 \%(\mathrm{v} / V)$ concentration of rapeseed extract was used (Fig. 2). The most satisfactory results were obtained for B. gladioli pv. alliicola. Density of the bacteria was significantly reduced by $53 \%$ and $97 \%$ for $20 \%$ and $30 \%$ addition of the extract, respectively. In contrast, the extract at $10 \%$ concentration did not produce satisfactory effect (results not presented). The extract was sterilized in autoclave and high temperature $\left(121^{\circ} \mathrm{C}\right)$ could have caused decrease of its activity (Smolińska et al. 1997). However, it still possessed antimicrobial activity. It was difficult to conduct this experiment with the fresh extract. The microorganisms present in this fresh extract overgrown agar medium and it was impossible to count colony of tested bacteria (results not presented). 


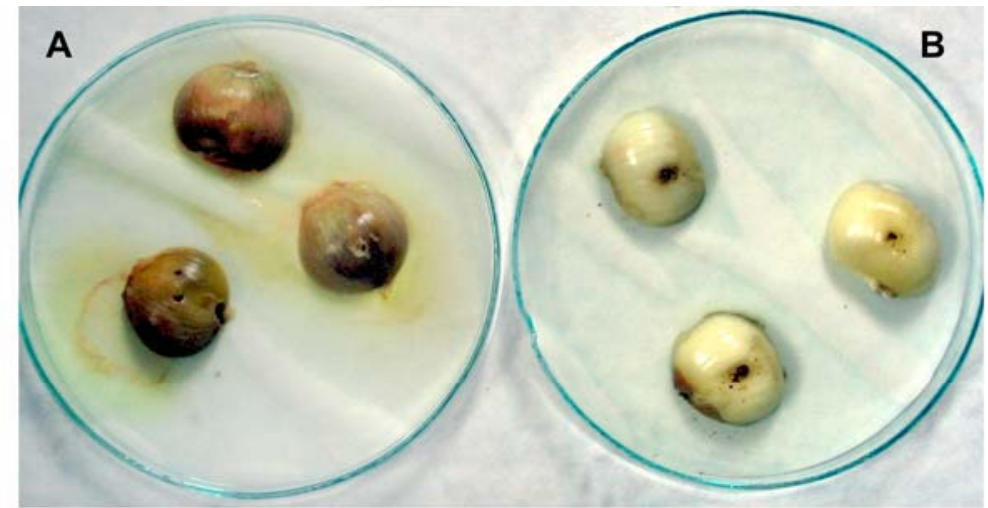

Photo 1. The effect of volatile compounds evolved from milled seeds of $B$. juncea $\mathrm{cv}$ Małopolska on the development of disease caused by P. carotovorum subsp. carotovorum on onion bulbs

A - inoculated control, B - P. carotovorum subsp. carotovorum + B. juncea

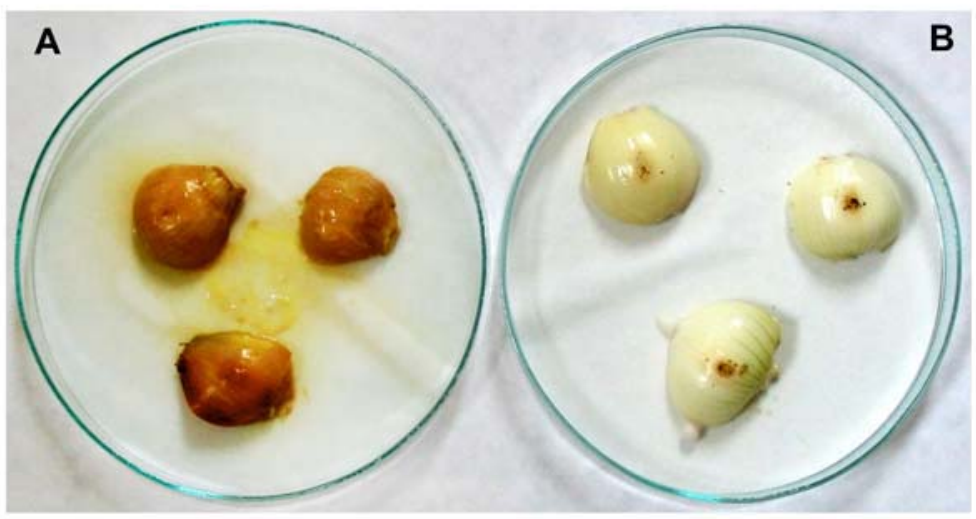

Photo 2. The effect of volatile compounds evolved from milled seeds of B. napus cv. Kana on the development of disease caused by $B$. gladioli pv. alliicola on onion bulbs A - inoculated control, B - B. gladioli pv. alliicola + B. napus
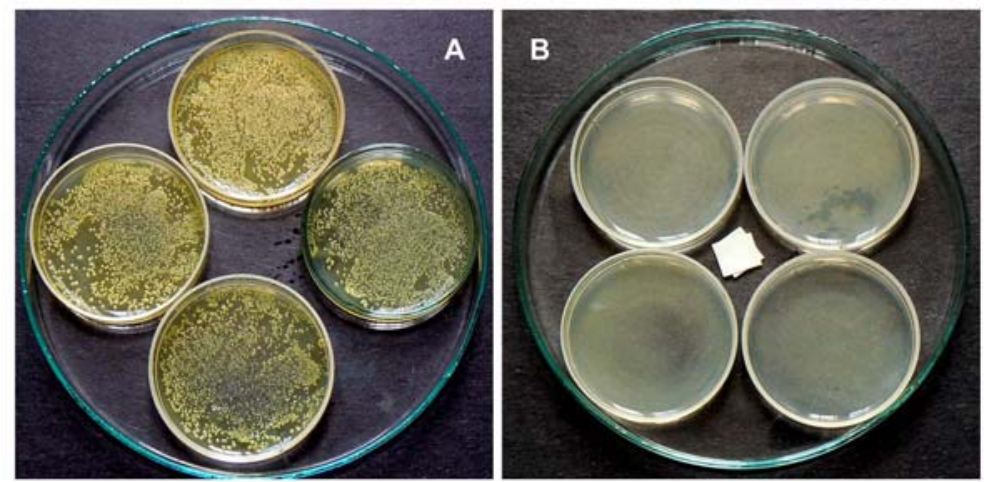

Photo 3. The effect of volatile compounds evolved from 2-propenyl ITC on the growth of $B$. cepacia

A - control, B - $5 \mu \mathrm{L}$ of 2-propenyl ITC dropped onto the filter paper 


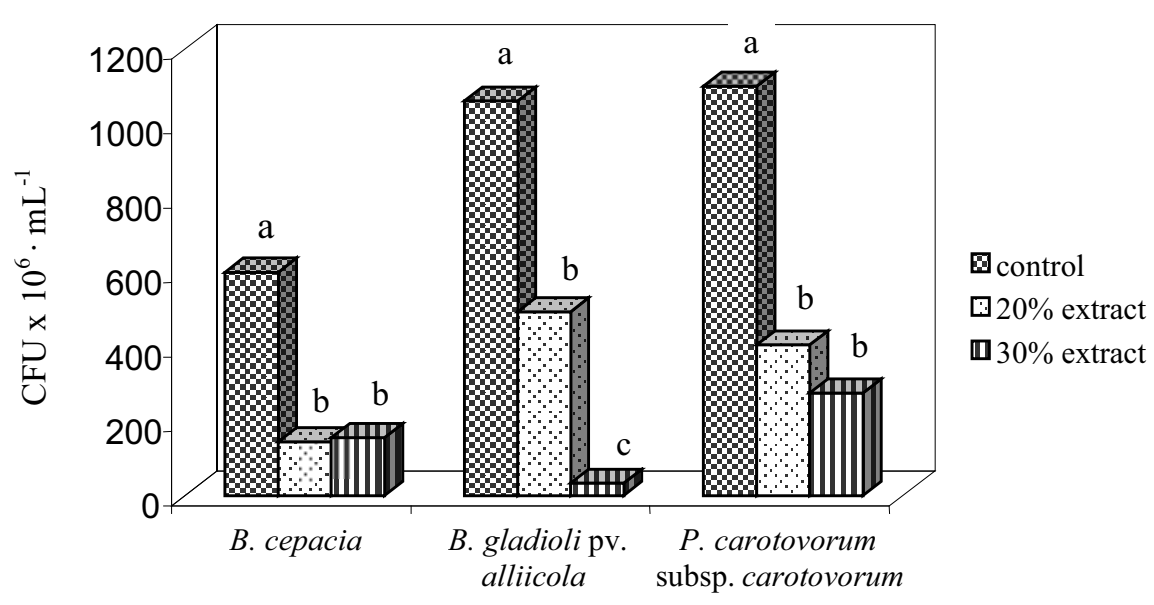

Fig. 2. The effect $20 \%$ and $30 \%$ water extract from rapeseed B. napus cv. Kana on the growth of tested bacteria B. cepacia, B. gladioli pv. alliicola and P. carotovorum subsp. carotovorum

Note: see Fig. 1

Table 2. The effect of volatile compound - 2-propenyl ITC on the growth of B. cepacia, B. gladioli pv. alliicola and P. carotovorum subsp. carotovorum

\begin{tabular}{lccc}
\hline Treatment & $\begin{array}{c}\text { B. cepacia } \\
\text { CFU'mL }\end{array}$ & $\begin{array}{c}\text { B. gladioli } \mathrm{pv} \text {. allicola } \\
\mathrm{CFU} \cdot \mathrm{mL}^{-1}\end{array}$ & $\begin{array}{c}\text { P. carotovorum } \\
\text { subsp. carotovorum } \\
\text { CFU } \cdot \mathrm{mL}^{-1}\end{array}$ \\
\hline control & $22.8 \times 10^{6}$ & $7.7 \times 10^{6}$ & $52 \times 10^{6}$ \\
$10 \mu \mathrm{L}$ & less than $1.0 \times 10^{2}$ & less than $1.0 \times 10^{2}$ & less than $1.0 \times 10^{2}$ \\
$5 \mu \mathrm{L}$ & less than $1.0 \times 10^{2}$ & less than $1.0 \times 10^{2}$ & less than $1.0 \times 10^{2}$ \\
\hline
\end{tabular}

The experiment with addition of water extract from tomato cv. Remiz to nutrient broth showed that the extract had antibacterial activity and the growth of tested bacteria was inhibited. The most toxic effect was obtained for $B$. cepacia. There was a 10 -fold decrease in number of the bacteria compared to control. The extract towards B. gladioli pv. alliicola and $P$. carotovorum subsp. carotovorum presented slightly weaker toxic activity. For these two bacteria comparable results were obtained in experiment with onion bulbs. The development of disease was reduced by $48 \%$ and $28 \%$ in case of B. gladioli pv. alliicola and P. carotovorum subsp. carotovorum, respectively (Fig. 3). However, the extract was completely ineffective in inhibition of disease development caused by B. cepacia. 


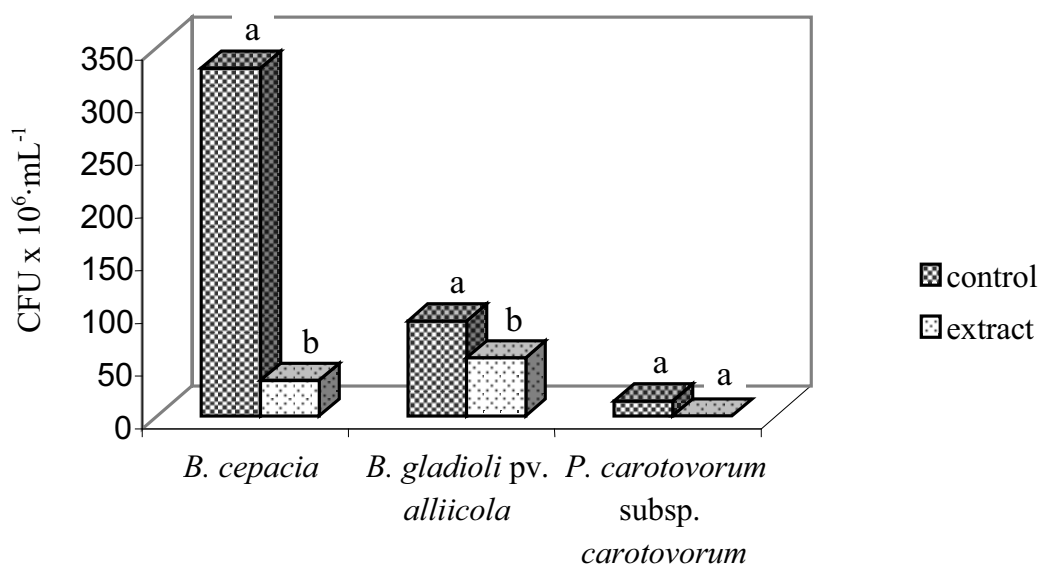

Fig. 3. The effect of $10 \%$ water extract from tomato L. esculentum cv. Remiz on the growth of B. cepacia, B. gladioli pv. alliicola and P. carotovorum subsp. carotovorum

Note: see Fig. 1

The commercial products Funguran Easy $50 \mathrm{WP}$ and Biosept 33 SL showed very weak activity in protection of onion against $B$. cepacia, $B$. gladioli pv. alliicola and $P$. carotovorum subsp. carotovorum. However, both of these agents are recommended for controlling bacterial diseases during cultivation of onion.

The obtained results showed that $B$. juncea, B. napus and L. esculentum contain active compounds which decreased survival of bacterial pathogens of onion. The application of $B$. juncea milled seeds to control or eliminate bacterial pathogens such as $P$. carotovorum subsp. carotovorum, B. cepacia, $B$. gladioli pv. alliicola may be possible. In the event of the lack of effective agents in plant protection against bacterial diseases, these plant materials could be used as a source of biological active compounds in integrated and ecological control methods. Further research is needed in order to obtain information regarding the practical effectiveness of these plant materials in onion protection.

\section{CONCLUSIONS}

Seeds of B. juncea cv. Małopolska, water extracts from B. napus cv. Kana and $L$. esculentum cv. Remiz contained compounds which exhibited toxic activity towards $P$. carotovorum subsp. carotovorum, B. cepacia and B. gladioli pv. alliicola. The strongest inhibitory effect in bacterial disease development on onion bulbs showed milled seeds of B. juncea cv. Małopolska, both used as a source of volatile compounds and also in direct contact with inoculated place on onion bulb. Probably 2-propenyl ITC present in high concentration in mustard tissues was responsible for this effect. The obtained results showed that Bras- 
sica plants could be used in organic and integrated farming in the protection of vegetables against bacterial diseases.

\section{REFERENCES}

Bahraminejad S., Asenstorfer R.E., Riley I.T., Schultz C.J. 2008. Analysis of the antimicrobial activity of flavonoids and saponins isolated from the shoots of oats (Avena sativa L.). J. Phytopathology 156: 1-7. [DOI: 10.1111/j.1439-0434.2007.01309.x]

Brown P.D., Morra M.J. 1997. Control of soil-borne plants pests using glucosinolatecontaining plants. Adv. Agron. 61: 167-231.

Coventry E., Allan E.J. 2001. Microbiological and chemical analysis of neem (Azadirachta indica) extracts: new data on antimicrobial activity. Phytoparasitica 29 (5): 441-450.

Cowan M.M. 1999. Plant products as antimicrobial agents. Clinic. Microbiol. Rev. 12 (4): 564-582.

Curtis H., Noll U., Störmann J., Slusarenko A.J. 2004. Broad-spectrum activity of volatile phytoanticipin allicin in extracts of garlic (Allium sativum L.) against plant pathogenic bacteria, fungi and Oomycetes. Physiol. Mol. Plant Pathol. 65: 79-89. [DOI: 10.1016/j.pmpp.2004.11.006]

Daferera D.J., Ziogas B.N., Polissiou M.G. 2003. The effectiveness of plant essential oils on the growth of Botrytis cinerea, Fusarium sp. and Clavibacter michiganensis subsp. michiganensis. Crop Protection 22: 39-44.

Gardiner J.B., Morra M.J., Eberlein Ch.V., Brown P.D., Borek V. 1999. Allelochemicals released in soil following incorporation of rapeseed (Brassica napus) green manures. J. Agric. Food Chem. 47: 3837-3842.

Horbowicz M. 2003. The occurrence, role and contents of glucosinolates in Brassica vegetables. Veget. Crops Res. Bull. 58: 23-40.

Iacobellis N.S., Lo Cantore P. 2005. Potential use of essential oils for plant bacterial disease control. The First Symposium on Biological Control of Bacterial Diseases in Darmstadt. Berichte Biol. Bundesanst. Land-Forstwirtsch. 128: 33.

Kokoškovă B., Roman P. 2005. Effectivity of essential oils against pectinolytic erwinias and pseudomonads. The First Symposium on Biological Control of Bacterial Diseases in Darmstadt. Berichte Biol. Bundesanst. Land-Forstwirtsch. 128: 65.

Krupiński G., Sobiczewski P. 2001. Wpływ ekstraktów roślinnych na wzrost Erwinia amylovora (Burrill) Winslow et al. Acta Agrobotanica 54(2): 81-91. [in Polish with English summary]

Lachman J., Hamouz K., Orsák M., Pivec V. 2001. Potato glycoalkaloides and their significance in plant protection and human nutrition - review. Series Rostlinná Vy̆roba 47: 181-191.

Łojkowska E., Królicka A., Biskup E. 2005. Antibacterial activity of plant extracts against bacterial plant pathogens. The First Symposium on Biological Control of Bacterial Diseases in Darmstadt. Berichte Biol. Bundesanst. Land-Forstwirtsch. 128: 68.

Martyniuk S., Jurzysta M., Wróblewska B. 1999. Influence of powdered aerial parts of various Medicago species on the growth of Gaeumannomyces graminis and Cephalosporium gramineum. Bull. Pol. Ac. Scien. 47 (2-4): 163-166.

Orlikowski L.B., Skrzypczak C. 2003. Grapefriut extract as biocontrol agent of soilborne and leaf pathogens. Bull. Pol. Ac. Scien. 51(2): 79-85.

Ozturk S., Ercisli S. 2007. Antibacterial activity and chemical constitutions of Ziziphora clinopodioides. Food Control 18: 535-540. [DOI: 10.1016/j.foodcont.2006.01.002] 
Rosa E.A.S., Rodrigues P.M.F. 1999. Towards a more sustainable agriculture system: The effect of glucosinolates on the control of soil-borne diseases. J. Hort. Sci. \& Biotechnol. 74 (6): 667-674.

Salles J.F., Samyn E., Vandamme P., van Veen J.A., van Elsas J.D. 2006. Changes in agricultural management drive the diversity of Burkholderia species isolated from soil on PCAT medium. Soil Biology \& Biochemistry 38 (4): 661-673. [DOI: $10.1016 /$ j.soilbio.2005.06.018]

Schaad N.W., Jones J.B., Chun W. 2001. Laboratory guide for identification of plant pathogenic bacteria. APS Press. Minnesota.

Smolińska U., Horbowicz M. 1999. Fungicidal activity of volatiles from selected cruciferous plants against resting propagules of soil-borne fungal pathogens. J. Phytopathology 147: 119-124.

Smolińska U., Morra M.J., Knudsen G.R., Brown P.D. 1997. Toxicity of glucosinolate degradation products from Brassica napus seed meal toward Aphanomyces euteiches f.sp. pisi. Phytopathology 87: 77-82.

Smolińska U. 2004. Badania nad możliwością wykorzystania roślin Brassicaceae, zawierających związki biologicznie czynne, w ograniczaniu Sclerotium cepivorum BERK. Rozprawa habilitacyjna. Skierniewice. [in Polish with English summary]

Sobiczewski P., Schollenberger M. 2002. Bakteryjne choroby roślin ogrodniczych. Państwowe Wydawnictwo Rolnicze i Leśne. Warszawa: 54-57; 64-67. [in Polish]

Soylu S., Soylu E.M., Baysal Ö., Zeller W. 2005. Antibacterial activities of essential oils from medicinal plants against the growth of Clavibacter michiganensis subsp. michiganensis. The First Symposium on Biological Control of Bacterial Diseases in Darmstadt. Berichte Biol. Bundesanst. Land-Forstwirtsch. 128: 76.

Tabanca N., Demirci B., Crockett S.L., Baser K.C.B., Wedge E. 2007. Chemical composition and antifungal activity of Arnica longifolia, Aster hesperius, and Chrysothamnus nauseosus essential oils. J. Agric. Food Chem. 55 (21): 84308435.

Utama I.M.S., Wills R.B.H., Ben-Yehoshua S., Kuek C. 2002. In vitro efficacy of plant volatiles for inhibiting the growth of fruit and vegetable decay microorganisms. J. Agric. Food Chem. 50: 6371-6377.

Vasinauskiene M., Radusiene J., Zitikaite I., Surviliene E. 2006. Antibacterial activities of essential oils from aromatic and medicinal plants against growth of phytopathogenic bacteria. Agronomy Research 4: 437-440.

\section{WPŁYW WYBRANYCH MATERIAŁÓW I EKSTRAKTÓW ROŚLINNYCH NA ROZWÓJ CHORÓB BAKTERYJNYCH CEBULI}

\section{Streszczenie}

Badano antybakteryjne działanie materiałów pochodzących z roślin Brassicaceae i Solanaceae oraz wodnych wyciagów z tych roślin na wzrost patogenicznych dla cebuli (Allium cepa L.) bakterii B. cepacia, B. gladioli pv. alliicola i P. carotovorum subsp. carotovorum oraz na rozwój bakterioz powodowanych przez te patogeny. Toksyczne działanie było uzależnione od rodzaju użytego materiału oraz od gatunku bakterii.

Wodne wyciagi z Brassica napus odm. Kana oraz z Lycopersicon esculentum odm. Remiz zmniejszały liczebność wszystkich badanych bakterii. Zmielone nasiona Brassica juncea odm. Małopolska wykazywały toksyczny efekt w stosunku do $B$ cepacia i B. gladioli pv. alliicola, natomiast zmielone nasiona B. napus odm. Kana nie wpływały na zmniejszenie liczebności badanych bakterii. 
W doświadczeniu mającym na celu określenie wpływu badanego materiału roślinnego na rozwój chorób bakteryjnych cebuli, najsilniejsze działanie hamujące stwierdzono w przypadku zmielonych nasion $B$. juncea odm. Małopolska. Materiał ten, zastosowany zarówno jako źródło związków lotnych, jak również w przypadku bezpośredniego kontaktu z miejscem infekcji, hamował rozwój choroby w przypadku wszystkich badanych patogenów. B. juncea zawiera dużą ilość izotiocyjanianu 2-propenylu i najprawdopodobniej ten związek wpływał negatywnie na rozwój bakterii. Zastosowany w badaniach komercyjny izotiocyjanian 2-propenylu działał toksycznie na badane bakterie oraz hamował rozwój bakterioz. Komercyjne produkty - Funguran Easy 50WP oraz Biosept 33SL wykazywały bardzo słabe ochronne działanie. 